\title{
PENGARUH INTERAKSI GENOTIP DAN LINGKUNGAN TERHADAP PENINGKATAN PRODUKTIVITAS TANAMAN BAWANG MERAH MENGGUNAKAN METODE SEM-AMMI
}

\section{The Influece of Genotype and Environment Interaction on Improved Productivity of the Red Onion Plant Used SEM-AMMI Method}

\author{
Ghina Rizqa Raihanah ${ }^{1 *}$, Junaidi ${ }^{2}$, Fadjryani ${ }^{3}$ \\ 1,2,3 Program Studi Statistika Fakultas MIPA Universitas Tadulako \\ Jln. Soekarno Hatta Km. 9, Palu-Sulawesi Tengah, 94118, Indonesia
}

Corresponding author e-mail: ${ }^{1 *}$ ghinarizqa10@gmail.com

\begin{abstract}
Abstrak
Varietas unggul yang stabil dan adaptif memegang peranan penting dalam meningkatkan produktivitas tanaman. Inovasi teknologi tersebut dilakukan dengan mengkaji IGL daya hasil. Namun, jika hanya memperhatikan IGL daya hasil tentunya belum cukup dalam pemilihan varietas unggul yang stabil dan adaptif sehingga penelitian ini menggunakan penggabungan metode AMMI dan SEM. Melalui SEM-AMMI dilakukan pemodelan IGL dengan memperhatikan proses fisiologi pertumbuhan dan perkembangan genotip yang menjelaskan keterkaitan IGL komponen daya hasil dan bagaimana pengaruhnya terhadap IGL hasil. Hasil biplot AMMI menunjukkan genotip yang dapat beradaptasi dan relatif stabil ditanam pada lima lokasi tanam adalah Biru Lancor dan Tinombo. Hasil uji SEM menunjukkan komponen daya hasil berpengaruh terhadap hasil produksi dimana bobot umbi di atas rata-rata akan memberikan hasil produksi bawang merah yang relatif lebih banyak serta genotip yang ditanam pada lokasi relatif rendah, $\mathrm{pH}$ tanah di atas 6 serta kondisi tanah lempung berdebu akan menghasilkan bawang merah relatif lebih banyak dan berkualitas.
\end{abstract}

Kata Kunci: AMMI, bawang merah, IGL, SEM

\begin{abstract}
Stable and adaptive superior varieties play an important role in increasing plant productivity. The technological innovation was carried out by studying of the yield GEI. However, if only paying attention to yield GEI would not be enough in selecting stable and adaptive varieties, so this research used a combination of AMMI and SEM methods. Through the SEM-AMMI, GEI modeling was carried out by taking into account the physiological processes of growth and genotype development which explained the relationship between yield GEI components and how it affected yield GEI. The results of the AMMI biplot showed that genotypes were adaptable and relatively stable were planted in five planting locations, namely Biru Lancor and Tinombo. SEM test results showed that the yield component has an effect on production yield, where the tuber weight above the average will gave relatively more onion yields and genotypes planted in relatively low locations, soil pH above 6 and dusty clay soil conditions will produce relatively more red onions and quality.
\end{abstract}

Keywords: AMMI, red onion, GEI, SEM

Article info:

Received: 04 $4^{\text {th }}$ January 2021 Accepted: $24^{\text {th }}$ February 2021

How to cite this article:

G. R. Raihanah, Junaidi, Fadjryani, "PENGARUH INTERAKSI GENOTIP DAN LINGKUNGAN TERHADAP ENINGKATAN PRODUKTIVITAS TANAMAN BAWANG MERAH MENGGUNAKAN METODE SEM-AMMI ", BAREKENG: J. Il. Mat. \& Ter., vol. 15, no. 1, pp. 115-126, Mar. 2021.

\section{(i) (2)}

This work is licensed under a Creative Commons Attribution-ShareAlike 4.0 International License.

Copyright (C) 2021 Ghina Rizqa Raihanah, Junaidi, Fadjryani 


\section{PENDAHULUAN}

Sulawesi Tengah merupakan salah satu Propinsi di Indonesia yang memiliki potensi besar dalam bidang pertanian. Potensi tersebut didukung oleh tingkat kesuburan tanah yang baik, ketersediaan air tanah maupun air hujan, dan iklim yang sesuai [1]. Salah satu komoditas agribisnis yang dapat dibudidayakan di Sulawesi Tengah diantaranya adalah bawang merah yang merupakan komoditas unggulan holtikultura di Sulawesi Tengah [2]. Sulawesi Tengah khususnya di Kabupaten Sigi memiliki potensi lahan yang cukup luas yaitu sebesar 84,175 Ha dengan luas lahan kering sebesar 109.32 ribu Ha yang merupakan daerah potensi untuk pengembangan bawang merah [3]. Hal tersebut memberikan gambaran bahwa masih besarnya peluang petani bawang merah untuk meningkatkan hasil produksi bawang merah dalam memenuhi permintaan dan kebutuhan konsumi bawang merah.

Berdasarkan hasil Survei Sosial Ekonomi Nasional (SUSENAS) perkembangan konsumsi bawang merah dari tahun 1981 sampai 2014 cenderung mengalami kenaikan dengan rata-rata pertumbuhan sebesar $8.69 \% \mathrm{~kg} / \mathrm{kap} /$ tahun kemudian pada tahun 2015 konsumsi bawang merah diproyeksikan naik sebesar 2.49 $\mathrm{kg} / \mathrm{kap} /$ tahun dengan konsumsi nasional bawang merah sebesar 637,966 ton [3]. Data tersebut membuktikan bahwa banyaknya permintaan dan kebutuhan bawang merah yang terus meningkat setiap tahunnya belum dapat diikuti oleh peningkatan produksinya. Hal ini disebabkan oleh keterbatasan dalam hal budidaya tanaman salah satunya keragaman jenis tanaman. Pengembangan tanaman bawang merah diarahkan pada kesesuaian faktor fisik lingkungan secara optimal. Dalam kaitan dengan hal tersebut, ketersediaan varietas yang sesuai dengan lingkungan setempat dan berpotensi memperoduksi hasil yang tinggi merupakan faktor yang secara langsung mempengaruhi daya hasil dan adaptasi varietas [4].

Percobaan multilokasi merupakan percobaan yang sering dilakukan dalam penelitian pemuliaan tanaman untuk mengkaji interaksi genotip dan lingkungan (IGL) [5]. Beberapa metode statistik yang digunakan untuk mengkaji IGL diantaranya adalah metode Factorial Regression (FR) dan Partial Least Square Regression (PLSR) [6]. Namun kedua metode ini gagal dalam menjelaskan keterkaitan anatara IGL karakteristik agronomi dengan IGL hasil sebagai suatu rangkaian proses fisiologis yang bekerja dalam sebuah sistem persamaan [7] sehingga, peneliti menggunakan penggabungan metode Additive Main Effect and Multiplicative Interaction (AMMI) dengan Structural Equation Modeling (SEM) dalam menjelaskan interaksi genotip dan lingkungan yang dikenal dengan SEM-AMMI. Metode SEM-AMMI dapat melakukan pemodelan IGL dengan memperhatikan proses fisiologi pertumbuhan dan perkembangan genotip yang menjelaskan bagaimana keterkaitan IGL karakteristik argonomi dan bagaimana pengaruhnya terhadap IGL hasil. SEM-AMMI juga mampu menjelaskan bagaimana pengaruh kovariat genotip dengan lingkungan terhadap interaksi genotip dan lingkungan untuk karakteristik agronomi dan hasil

Terdapat beberapa penelitian sebelumnya yang telah menerapkan metode SEM-AMMI, yaitu "Analysis of Genotype-by-Environment Interaction in Wheat Using a Structural Equation Model and Chromosome Substitution Lines" dengan studi kasus daya hasil produksi padi. Diperoleh hasil bahwa variabel SPSM IGL memiliki efek langsung tertinggi pada hasil IGL serta penanda genetik sebagian besar sensitif terhadap suhu dan curah hujan selama masa vegetatif dan reproduksi [6]. Kemudian, penelitian "Analisis Interaksi Genotipe x Lingkungan Menggunakan Model Persamaan Struktural", dimana hasil penelitian tersebut digunakan untuk mertimbangkan genotip unggulan dan dikembangkan menjadi varietas [11].

Berdasarkan uraian dari latar belakang diatas, penulis tertarik melakukan sebuah penelitian dengan menerapkan metode SEM-AMMI untuk menjelaskan interaksi antara genotip dan lingkungan pada hasil tanaman bawang merah di Kabupaten Sigi dengan memperhatikan proses fisiologi pertumbuhan dan perkembangan genotip.

\section{METODE PENELITIAN}

\subsection{Additive Main Effect and Multiplicative Interaction}

Analisis AMMI adalah suatu teknik analisis data percobaan dua faktor perlakuan dengan pengaruh utama perlakuan bersifat aditif, sedangkan pengaruh interaksi dimodelkan dengan model bilinier. Model AMMI dapat digunakan untuk menganalisis percobaan lokasi ganda. Pada dasarnya analisis AMMI menggabungkan analisis ragam aditif terhadap pengaruh utama perlakuan dengan analisis komponen utama ganda dan model bilinier pada pengaruh interaksi [8]. 
Melalui AMMI matriks residual sebagai penyimpangan dari model aditif didekomposisi dengan menggunakan AKU (Analisis Komponen Utama) untuk mendapatkan bagian multiplikatif dari model. AKU memusatkan pola utama dari variasi residual ke dalam sedikit komponen utama dan sisanya adalah galat. Dengan cara ini, bagian multiplikatif pada AMMI dapat mempartisi data ke dalam pola model interaksi penuh dengan mempertimbangkan sedikit komponen utama dan membuang galat untuk ketepatan prediksi [9].

\subsection{Analisis Komponen Utama (AKU)}

Analisis Komponen Utama merupakan suatu teknik analisis statistik untuk mentransformasi variabelvariabel asli yang masih saling berkorelasi satu dengan yang lain menjadi satu set variabel baru yang tidak berkorelasi lagi. Variabel-variabel baru itu dinamakan komponen utama (KU) [10].

\subsection{Interpretasi Model AMMI}

Pengaruh interaksi genotip dan lingkungan digambarkan melalui biplot AMMI-2. Kedekatan jarak antar genotip dan lingkungan dan besar sudut yang terbentuk dari kedua titik tersebut mencerminkan adanya interaksi yang khas diantara keduanya. Kestabilan genotip diuji dengan pendekatan selang kepercayaan sebaran normal ganda yang berbentuk elips pada skor KUI-nya. Jika koordinat suatu genotip semakin dekat dengan pusat koordinatnya berarti genotip tersebut semakin stabil terhadap perubahan lingkungan. Dari biplot AMMI-2 dapat diperoleh gambaran genotip-genotip yang stabil dan spesifik lingkungan. Makin dekat jarak lingkungan dengan genotip, atau semakin kecil sudut diantra keduanya, maka semakin kuat interaksinya [11].

\subsection{Analisis Biplot}

Biplot berupa tampilan grafik dengan menumpangtindihkan vektor-vektor baris mewakili objek dan vektor-vektor kolom yang mewakili peubah dalam ruang berdimensi rendah $(<3)$. Analisis biplot dikembangkan atas dasar Dekomposisi Nilai Singular (DNS) atau Singular Value Decomposition (SVD) [12]. Terdapat informasi yang dapat diperoleh dari biplot antara lain ialah:

a. Kedekatan antar objek. Dua objek dengan karakteristik yang sama akan digambarkan sebagai dua titik yang posisinya berdekatan.

b. Keragaman peubah. Peubah dengan keragaman kecil digambarkan sebagai vektor yang pendek. Begitu pula sebaliknya, peubah dengan keragaman besar digambarkan sebagai vektor yang panjang.

c. Korelasi antar peubah. Peubah digambarkan sebagai vektor. Jika sudut dua peubah lancip $\left(<90^{\circ}\right)$ maka korelasinya bernilai positif. Apabila sudut dua peubah tumpul $\left(<90^{\circ}\right)$ maka korelasinya bernilai negatif. Sedangkan jika sudut dua peubah siku-siku maka tidak saling berkorelasi.

d. Keterkaitan peubah dengan objek. Karakteristik suatu objek bisa disimpulkan dari posisi relatifnya yang paling dekat dengan suatu peubah. Jika posisi objek searah dengan arah vektor peubah maka objek tersebut bernilai di atas rata-rata, jika berlawanan maka nilainya di bawah rata-rata, dan jika hampir di tengahtengah maka nilainya mendekati rata-rata.

\subsection{Structural Equation Modeling-Partial Least Square}

SEM-PLS merupakan sebuah pendekatan kausal yang bertujuan memaksimumkan variansi dari variabel laten endogen yang dapat dijelaskan (explained variance) oleh variabel laten eksogen. Partial Least Square adalah salah satu teknik pemodelan struktural yang seringkali disebut soft-modelling technique, karena merupakan metode analisis yang tidak memerlukan asumsi sebaran data tertentu karena menggunakan metode resampling sehingga dapat digunakan pada ukuran sampel kecil [13].

Di dalam SEM terdapat dua model indikator, yaitu model reflektif dan model formatif. SEM-PLS dapat sekaligus menganalisis konstruk yang dibentuk dengan indikator formatif dan reflektif sedangkan CB-SEM hanya menggunakan model reflektif. SEM memiliki 2 model, yaitu model struktural dan model pengukuran. Model struktural menggambarkan hubungan-hubungan yang ada di antara variabel-variabel laten. Parameter yang menunjukkan regresi variabel laten endogen pada variabel laten eksogen diberi label dengan $\gamma$ sedangkan untuk regresi variabel laten endogen pada variabel laten endogen diberi label dengan $\beta$. Model Pengukuran dalam model ini, setiap variabel laten dimodelkan sebagai sebuah faktor yang mendasari variabel-variabel teramati yang terkait. Muatan-muatan faktor yang menghubungkan variabel laten dengan variabel-variabel teramati diberi label dengan $\lambda[14]$. 


\subsection{Pendugaan Efek Langsung, Tidak Langsung, dan Total}

Model-model SEM pada umumnya melibatkan hubungan antar peubah bias langsung, atau tidak langsung terhadap peubahan lainnya [15].

a. $\quad$ Direct casual effect (Pengaruh Kasual Langsung $=\mathrm{PKL})$ adalah pengaruh satu variabel eksogen terhadap variabel endogen yang terjadi tanpa melalui variabel endogen lain.

b. Indirect casual effect (Pengaruh Kasual Tidak Langsung $=$ PKTL) adalah pengaruh satu variabel eksogen terhadap variabel endogen yang terjadi melalui variabel endogen lain yang terdapat dalam satu model kausalitas yang sedang dianalasis.

c. Total causal effect $($ Pengaruh Kausal Total $=$ PKT) adalah jumlah dari Pengaruh Kasual Langsung $=$ PKL dan Pengaruh Kasual Tidak Langsung $=$ PKTL atau PKT=PKL+PKTL.

\subsection{Rancangan Penelitian}

Penelitian ini menggunakan rancangan percobaan multilokasi yang dilaksanakan di lima desa penghasil bawang merah yang ada di Kabupaten Sigi. Berikut adalah variabel yang digunakan dalam penelitian ini:

Tabel 1. Variabel Penelitian

\begin{tabular}{ll}
\hline \multicolumn{1}{c}{ Variabel yang Diamati } & \multicolumn{1}{c}{ Satuan } \\
\hline Bobot Umbi (BU) & Gram (gr) \\
\hline Diameter Umbi (DU) & Centimeter (cm) \\
\hline Jumlah Umbi (JU) & Buah \\
\hline Tinggi Lokasi (TL) & Meter (m) \\
\hline Sifat Fisik Tanah (SFT) & $1=$ lempung berpasir \\
\cline { 2 - 2 } & $2=$ lempung berdebu \\
\hline Kadar Keasaman (pH Tanah) & $>7,0=$ tanah basa \\
\hline Hasil Produksi (HSL) & $<7,0=$ tanah masam \\
\hline
\end{tabular}

Data yang digunakan dalam penelitian ini adalah data primer yang diperoleh dari hasil penelitian tanaman bawang merah di lima lokasi di Kabupaten Sigi. Pemilihan Kabupaten Sigi didasarkan pada penelitian terdahulu yang menjelaskan bahwa wilayah Kabupaten Sigi memiliki potensi dalam pengembangan bawah merah. Populasi yang digunakan dalam penelitian ini adalah lokasi penanaman bawang merah di Sulawesi Tengah dan genotip bawang merah di Indonesia dimana sampel yang digunakan dalam penelitian ini, yaitu lima lokasi penanaman yang ada di Kabupaten Sigi dan enam genotip bawang merah. Pemilihan variabel-variabel tersebut didasarkan pada penelitian-penelitian terdahulu serta dari hasil diskusi bersama petani bawang merah yang sudah berpengalaman. Berikut adalah genotip dan lokasi penanaman yang digunakan dalam penelitian ini:

Tabel 2. Genotip dan Lokasi Penelitian

\begin{tabular}{ll}
\hline \multicolumn{1}{c}{ Genotip/Varietas } & \multicolumn{1}{c}{ Lokasi Penanaman } \\
\hline Bima Brebes (G1) & Kota Rindau (L1) \\
\hline Tajuk (G2) & Sidera (L2) \\
\hline Biru Lancor (G3) & Oloboju (L3) \\
\hline Tinombo (G4) & Wotunonju (L4) \\
\hline Palasa (G5) & Solouve (L5) \\
\hline Lembah Palu (G6) & \\
\hline
\end{tabular}




\subsection{Tahapan Analisis}

Berikut tahapan analisis dengan menggunakan Metode SEM-AMMI:

1. Mendesain eksperimen dengan menentukan rancangan percobaannya, genotipe, lokasi penanaman, banyaknya ulangan, kovariat genotipe dan kovariat lingkungan yang akan digunakan pada penelitian ini.

2. Melakukan eksperimen pada enam genotipe bawang merah di Kabupaten Sigi.

3. Pengambilan data eksperimen tanaman bawang merah.

4. Mengeksplorasi data hasil eksperimen, yaitu komponen daya hasil dan daya hasil bawang merah.

5. Pengujian asumsi, yaitu kebebasan galat, kehomogenan dan kenormalan galat.

6. Melakukan analisis ragam dengan menggunakan Rancangan Faktorial RAKL.

7. Melakukan pemodelan analisis AMMI.

8. Membuat biplot AMMI-1 dan AMMI-2 untuk menginterpretasikan hasil dari analisis AMMI.

9. Menggambar kerangka penelitian hubungan antara komponen daya hasil terhadap daya hasil bawang merah.

10. Mengestimasi jalur antar variabel laten dan antara variabel laten dengan variabel indikatornya.

11. Mengevaluasi model SEM.

12. Kesimpulan.

\section{HASIL DAN PEMBAHASAN}

\subsection{Eksplorasi Data}

Terdapat beberapa komponen daya hasil bawang merah yang akan dikaji dalam penelitian ini yaitu bobot umbi, diameter umbi, dan jumlah umbi bawang merah serta daya hasil produksi bawang merah. Hasil produksi merupakan salah satu karakteristik agronomi tanaman bawang merah yang diukur setelah panen dilakukan dengan satuan kilogram. Dari 6 genotip yang ditanam pada 5 lokasi menghasilkan rata-rata produksi yang bervariasi antar genotip. Berdasarkan Gambar 1. genotip yang menghasilkan produksi bawang merah paling sedikit, yaitu Genotip Tinombo dengan berat $0,25 \mathrm{~kg}$ yang ditanam di Sidera sedangkan genotip yang menghasilkan bawang merah paling banyak, yaitu Genotip Bima Brebes pada lokasi Kota Rindau dengan rata-rata hasil produksi sebesar $2,82 \mathrm{~kg}$.

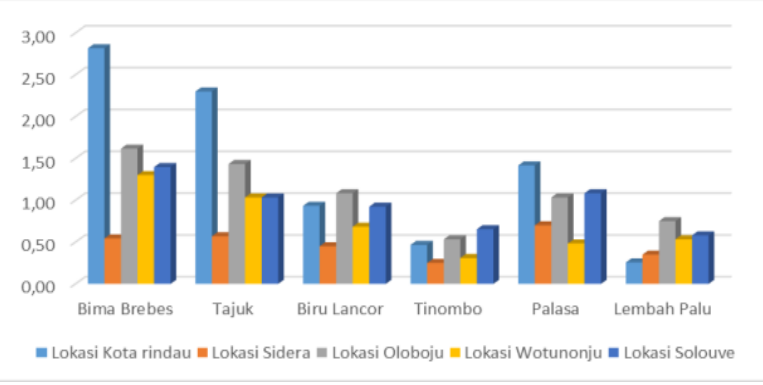

(a)

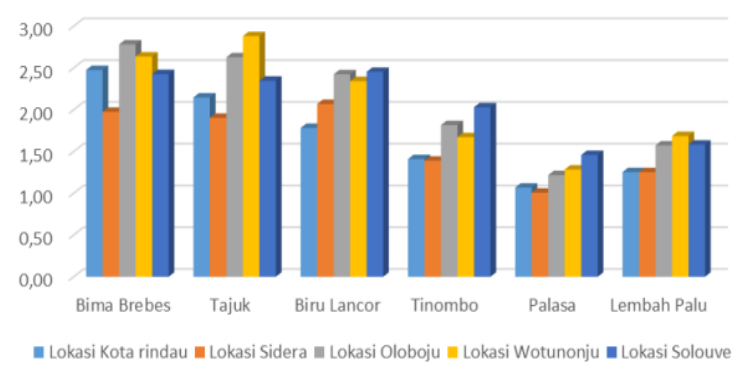

(c)

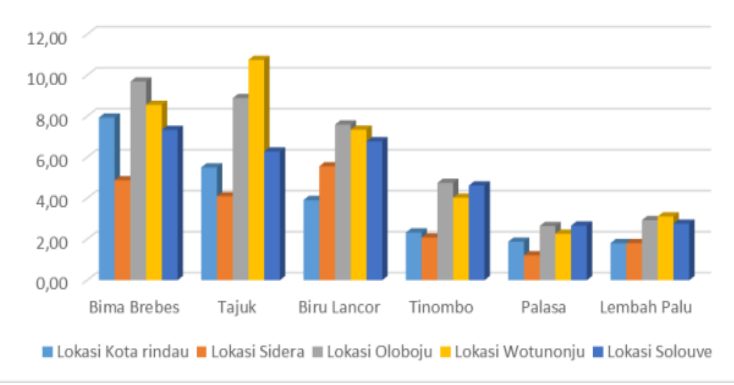

(b)

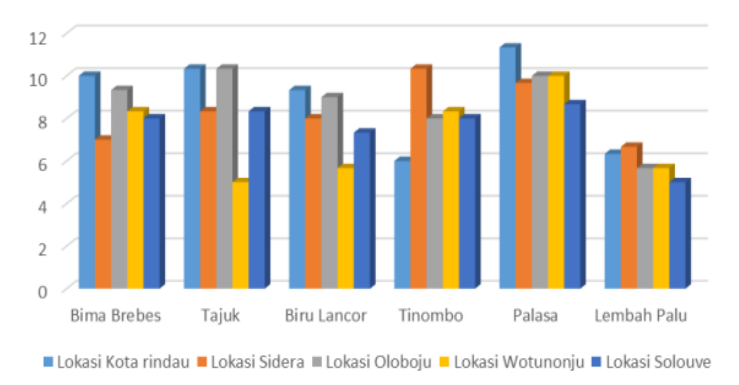

(d)

Gambar 1. (a) Hasil Produksi, (b) Bobot Umbi, (c) Diameter Umbi, (d) Jumlah Umbi 
Gambar 1. Juga dapat menjelaskan Genotip Palasa yang ditanam di Sidera mempunyai bobot umbi bawang merah yang terendah yaitu sebesar 1,21 gr sedangkan Genotip Tajuk mempunyai bobot umbi terberat yang ditanam di Wotunonju dengan berat rata-rata yaitu 10,746 gr. Selain itu, Genotip Palasa mempunyai diameter umbi bawang merah yang terkecil sebesar 1,21 cm/lokasi, sedangkan Genotip Bima Brebes mempunyai diameter umbi terbesar yaitu $2,458 \mathrm{~cm} /$ lokasi. Berikutnya untuk komponen daya hasil jumlah umbi, Genotip Lembah Palu mempunyai jumlah umbi bawang merah paling sedikit dengan total rataan dari kelima lokasi penanaman sebanyak 29 buah umbi, sedangkan Genotip Palasa mempunyai jumlah umbi terbanyak dari kelima genotip yang digunakan pada penelitian sebanyak 50 buah umbi.

\subsection{Pengujian Asumsi}

\section{a. Kenormalan Galat}

Pengujian kenormalan galat dilakukan dengan membuat plot kuantil-kuantil (Q-Q). Berdasarkan hasil pengujian didapatkan bahwa sebaran data pada keempat plot untuk keempat respon tersebut berada pada garis linier dan mengikuti garis linier. Hasil tersebut menunjukkan bahwa data hasil produksi, bobot umbi, diameter umbi dan jumlah umbi bawang merah berasal dari data yang berdistribusi normal.

\section{b. Kebebasan Galat}

Melihat keacakan galat percobaan dilakukan secara visual dengan membuat plot antara nilai dugaan galat percobaan $\left(e_{i j}\right)$ dengan nilai dugaan respon $\left(Y_{i j}\right)$. Hasil pengujian menunjukkan keempat plot tersebut titik-titik datanya tersebar secara acak dan tidak membentuk pola tertentu, maka dapat dikatakan bahwa galat percobaan saling bebas atau independent. Hasil tersebut menunjukkan bahwa asumsi kebebasan galat terpenuhi untuk semua respon, yaitu hasil produksi, bobot umbi, diameter umbi dan jumlah umbi bawang merah.

\section{c. Kehomogenan Gaat}

Uji yang digunakan untuk kehomogenan ragam adalah Uji Bartlett. Pengujian kehomogenan galat dilakukan dengan menggunakan tingkat kepercayaan 95\% atau dengan tingkat kesalahan $5 \%(\alpha=0,05)$. Berikut hipotesis uji kehomogenan galat:

$\mathrm{H}_{0}$ : ragam dari semua perlakuan pemberian genotipe sama.

$\mathrm{H}_{1}$ : paling sedikit ada satu dari ragam perlakuan pemberian genotipe.

Tabel 3. Hasil Uji Kehomogenan

\begin{tabular}{lcccc}
\hline \multicolumn{1}{c}{ Respon } & $\chi^{2}{ }_{\text {hitung }}$ & $\chi_{\text {tabel }}^{2}$ & Hipotesis & Keterangan \\
\hline Hasil produksi & $-0,255$ & 11,0705 & $\mathrm{H}_{0}$ diterima & Ragam homogen \\
\hline Bobot umbi & $-2,298$ & 11,0705 & $\mathrm{H}_{0}$ diterima & Ragam homogen \\
\hline Diameter umbi & $-6,82$ & 11,0705 & $\mathrm{H}_{0}$ diterima & Ragam homogen \\
\hline Jumlah umbi & $-5,115$ & 11.0705 & $\mathrm{H}_{0}$ diterima & Ragam homogen \\
\hline
\end{tabular}

Berdasarkan Tabel 3, dapat diketahui bahwa bobot umbi, diameter umbi, jumlah umbi, dan hasil produksi bawang merah mempunyai nilai $\chi^{2}{ }_{\text {hitung }} \leq \chi^{2}{ }_{\text {tabel }}$. Hasil tersebut menunjukkan bahwa $\mathrm{H}_{0}$ diterima sehingga komponen daya hasil (bobot, diameter dan jumlah umbi bawang merah per rumpun) dan daya hasil produksi bawang merah telah memenuhi asumsi kehomogenan ragam.

\section{d. Analisis Ragam (Analysis of Variance)}

Analisis ragam untuk pengujian pada daya hasil dan komponen daya hasil bawang merah menggunakan rancangan faktorial RAK. Bentuk hipotesis pada penelitian ini dapat disusun sebagai berikut:

1. Pengaruh utama genotipe:

$H_{0}: \alpha_{1}=\cdots=\alpha_{6}=0$ (genotipe tidak berpengaruh terhadap komponen daya hasil dan daya hasil)

$H_{1}: \alpha_{i} \neq 0$ (minimal ada satu genotipe berpengaruh terhadap komponen daya hasil dan daya hasil)

2. Pengaruh utama lingkungan: 
$H_{0}: \beta_{1}=\cdots=\beta_{5}=0$ (lingkungan tidak berpengaruh terhadap komponen daya hasil dan daya hasil) $H_{1}: \beta_{i} \neq 0$ (minimal ada satu lingkungan berpengaruh terhadap komponen daya hasil dan daya hasil)

3. Pengaruh interaksi genotipe dengan lingkungan:

$H_{0}: \alpha \beta_{1}=\cdots=\alpha \beta_{n}=0$ (interaksi dari genotipe dengan lingkungan tidak berpengaruh terhadap komponen daya hasil dan daya hasil)

$H_{1}: \alpha \beta_{i} \neq 0$ (minimal ada satu interaksi dari genotipe dengan lingkungan yang berpengaruh terhadap komponen daya hasil dan daya hasil)

4. Pengaruh pengelompokan:

$H_{0}: \rho_{1}=\cdots=\rho_{3}=0$ (blok tidak berpengaruh terhadap komponen daya hasil dan daya hasil)

$H_{1}: \rho_{i} \neq 0$ (minimal ada satu blok yang berpengaruh terhadap komponen daya hasil dan daya hasil)

Berdasarkan hasil analisis didapatkan bahwa pengaruh utama yaitu genotip dan lingkungan memberikan pengaruh yang signifikan terhadap komponen daya hasil (bobot, diameter, dan jumlah umbi bawang merah per rumpun) dan daya hasil produksi bawang merah yang ditunjukkan dengan nilai p-value lebih kecil dari $\alpha(0,05)$. Begitu juga untuk interaksi antara genotip dan lingkungan memberikan pengaruh terhadap komponen daya hasil dan daya hasil produksi bawang merah. Hasil tersebut dapat menjelaskan bahwa ada perbedaan rata-rata hasil produksi bawang merah dari genotipgenotip yang ditanam pada lingkungan yang berbeda, sehingga perlu dilakukan analisis AMMI untuk mengetahui genotip apa saja yang dapat beradaptasi dengan baik dan stabil pada lokasi tertentu dengan melihat komponen daya hasil dan daya hasil produksi bawang merah.

5. Analisis AMMI

Analisis AMMI dilakukan pada daya hasil produksi. Langkah pertama menguraikan pengaruh interaksi anatara genotip dan lokasi menggunakan Singular Value Decomposition (SVD) pada analisis AKU sehingga menghasilkan 4 komponen utama interaksi (KUI) dengan nilai akar ciri masing-masing KUI adalah 1,56601, 4,24007e-01, 1,96613e-01, dan 1,24266e-01. Dari nilai akar ciri tersebut dapat diketahui konstribusi keragaman pengaruh interaksi genotip dan lingkungan yang mampu diterangkan oleh masing-masing komponen utama adalah $91,29 \%, 6,69 \%, 1,44 \%$, dan 0,57\%.

Tabel 4. Analisis Ragam AMMI Untuk Hasil Produksi Bawang Merah

\begin{tabular}{crrrrr}
\hline Sumber Keragaman & DB & \multicolumn{1}{c}{ JK } & \multicolumn{1}{c}{ KT } & F hitung & $P$-value \\
\hline Lokasi & 4 & 8,2294 & 2,05736 & 50,7529 & 0,000 \\
\hline Genotip & 5 & 13,8626 & 2,77252 & 68,3952 & 0,000 \\
\hline Kelompok & 2 & 0,0528 & 0,02639 & 0,6510 & 0,5253 \\
\hline Genotip x Lokasi & 20 & 8,0519 & 0,40259 & 9,9315 & 0,000 \\
\hline KUI 1 & 8 & 7,3553 & 0,9194 & 22,6810 & 0,000 \\
\hline KUI 2 & 6 & 0,5378 & 0,0896 & 2,2115 & 0,054 \\
\hline KUI 3 & 4 & 0,1132 & 0,0283 & 0,6979 & 0,595 \\
\hline KUI 4 & 2 & 0,0454 & 0,0227 & 0,5609 & 0,574 \\
\hline Galat & 58 & 2,3511 & 0,04054 & & \\
\hline Total & 89 & 32,5478 & 5,2994 & &
\end{tabular}

Penentuan banyaknya komponen utama interaksi yang nyata diperoleh dengan metode Postdictive Success, yaitu banyaknya sumbu tersebut yang nyata pada uji $\mathrm{F}$ pada analisis ragam AMMI, Berdasarkan hasil uji $\mathrm{F}$, hanya komponen utama yang pertama yang signifikan dimana nilai $F_{\text {hitung }}(22,681)>F_{\text {tabel }}(2,1026)$ sehingga model AMMI tersebut mampu menerangkan keragaman pengaruh interaksi untuk IGL hasil produksi bawang merah sebesar 91,29\%. Untuk keperluan anaisis stabilitas dan aptabilitas, digunakan Biplot AMMI-2 beserta selang kepercayaan elips. Biplot AMMI2 merupakan plot antara KUI1 dengan KUI2 yang menjelaskan struktur interaksi antara genotip dan lingkungan. 


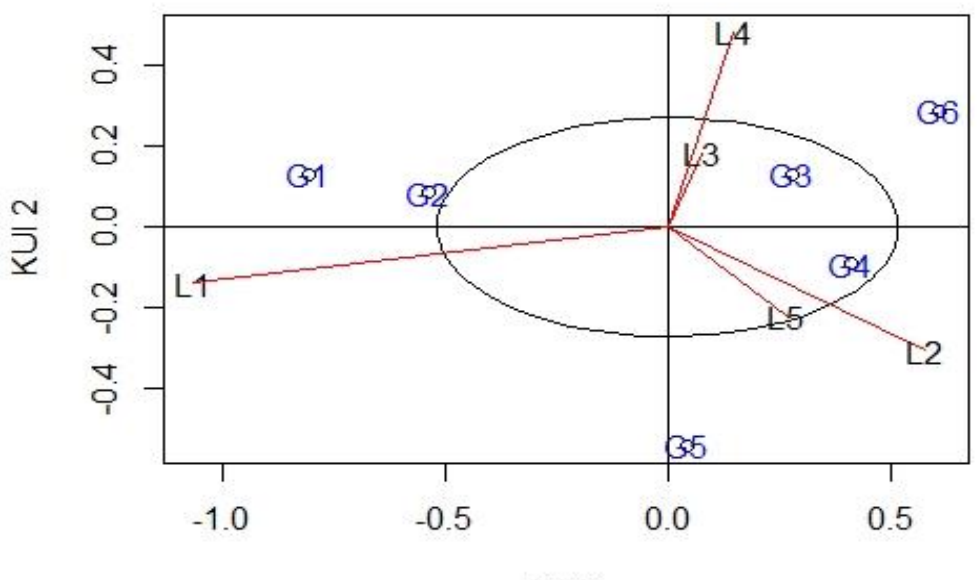

KUI 1

Gambar 2. Biplot AMMI-2 Hasil Produksi Bawang Merah

Berdasarkan hasil biplot AMMI-2 untuk daya hasil produksi bawang merah dapat menggambarkan keragaman interaksi genotip dan lingkungan sebesar 97,98\%. Keragaman interaksi yang dijelaskan oleh model AMMI-2 besar karena nilainya lebih besar dari 50\%. Pada Gambar 2, memperlihatkan bahwa terdapat dua genotip yang mempuyai hasil produksi bawang merah yang relatif stabil terhadap kelima lokasi penanaman di Kabupaten Sigi, yaitu Biru Lancor (G3) dan Tinombo (G4). Genotip tersebut yang mempunyai hasil produksi bawang merah yang stabil adalah genotip-genotip yang posisinya berada dalam elips pada titik pusat $(0,0)$. Keempat genotip yaitu Bima Brebes (G1), Tajuk (G2), Palasa (G5), dan Lembah Palu (G6) berada diluar ellips, jauh dari sumbu utama dan garis lokasi. Hasil tersebut menunjukkan bahwa keempat genotip tersebut cenderung tidak stabil atau tidak dapat beradaptasi dengan baik pada lima lokasi penanaman.

\section{Analisis IGL Menggunakan SEM-AMMI}

Analisis Structural Equation Modeling (SEM) akan dikombinasikan dengan pemodelan AMMI untuk membantu memberikan penjelasan faktor-faktor yang mempengaruhi siginifikansi efek interaksi genotip dan lokasi dimana faktor-faktor tersebut adalah komponen-komponen dari daya hasil dan juga faktor genotip dan lingkungan yang selama ini dalam kajian tentang interaksi genotip dan lokasi sering terabaikan, dimana faktor-faktor tersebut dinilai memiliki peran penting dalam menjelaskan interaksi genotip dan lokasi khususnya dalam menemukan varietas unggulan. Untuk memberikan hasil penjelasan secara komperhensif bagaimana IGL hasil dipengaruhi oleh beberapa IGL komponen daya hasil, daya hasil dan kombinasi kovariat genotip dengan lingkungan akan dijelaskan melalui penggabungan metode AMMI dan Structural Equation Modeling (SEM) yang disebut dengan SEMAMMI.

Pada analisis SEM melibatkan variabel eksogen dan varabel endogen. Variabel eksogen dalam kasus ini adalah interaksi antara kovariat genotip dan kovariat lokasi/lingkungan, sedangkan variabel endogenya adalah IGL untuk komponen daya hasil dan IGL daya hasil produksi bawang merah. Pembentukan diagram jalur (diagram path) pada model indikator menggunakan model formatif sehingga arah hubungan kausalitas dari indikator ke variabel laten Komponen-komponen daya hasil produksi bawang merah yang dilibatkan dalam penelitian ini adalah bobot umbi, diameter umbi dan jumlah umbi bawang merah. 


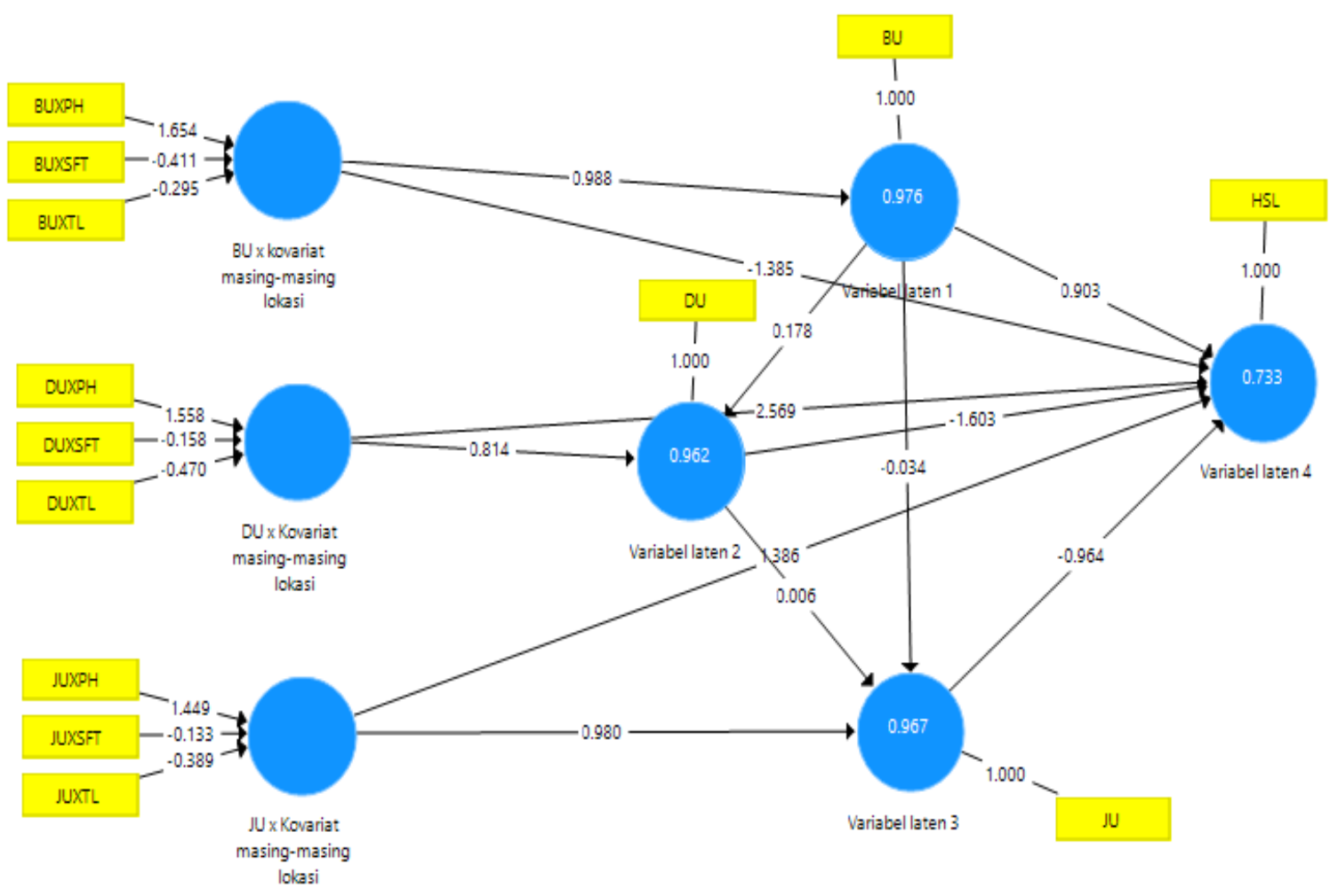

Gambar 3. Diagram Path SEM-AMMI

Gambar 3, menunjukkan hasil diagram lintas SEM dari pemodelan SEM-AMMI. Selain itu, dapat diketahui pula nilai loading factor (outer loading), path coefficients (inner path) dan nilai $\mathrm{R}$ square sebagai nilai baku pada model. Dari model yang telah ingin diketahui apakah model tersebut sudah fit atau belum, maka akan dilakukan evaluasi model dengan melihat nilai kecocokan model. Berikut hasil nilai kecocokan model SEM yang disajikan dalam Tabel 5:

Tabel 5. Nilai Kecocokan Model

\begin{tabular}{cccc}
\hline & Saturated Model & Kriteria & Keterangan \\
\hline SRMR & 0,086 & SMSR $<0,1$ & Model fit \\
\hline Chi-Square $\left(\chi^{2}\right)$ & 116,442 & $\chi^{2}{ }_{\text {hitung }}>\chi^{2}{ }_{\text {tabel }}(42,56)$ & Model fit \\
\hline NFI & 0,831 & NFI $>0,8$ & Model fit
\end{tabular}

Tabel 5, di atas menunjukkan hasil pengujian kecocokan model yang telah terbentuk, Diketahui bahwa nilai Standard Root Mean Square Residual (SRMR) sebesar 0,086. Nilai tersebut lebih kecil dari 0,1 yang berarti bahwa model telah cocok/fit. Kemudian didapatkan nilai $\chi^{2}{ }_{\text {hitung }}$ sebesar 116,44. Jika dibandingkan dengan nilai $\chi_{\text {tabel }}^{2}$ sebesar 42,56, maka $\chi_{\text {hitung }}^{2}$ lebih besar dari $\chi_{\text {tabel }}^{2}$ yang mengindikasikan bahwa model telah fit. Kemudian nilai Normed Fit Index (NFI) sebesar 0,831. Nilai NFI harus lebih besar dari 0,8 dan mendekati nilai 1. Semakin dekat nilai NFI ke 1, semakin baik kesesuaiannya. Berdasarkan output dan penjelasan di atas, diperoleh nilai kecocokan model yang sudah memenuhi kriteria model fit. Berdasarkan output dan penjelasan di atas, diperoleh nilai kecocokan model yang sudah memenuhi kriteria model fit, Hasil tersebut menunjukkan bahwa model yang dibangun mampu menjelaskan keragaman data dengan baik sehingga kesimpulan dari hasil analisis ini dapat diterima. 
Tabel 6. Pengaruh Langsung, Tak Langsung, dan Total

\begin{tabular}{lccc}
\hline \multicolumn{1}{c}{ Variabel } & $\begin{array}{c}\text { Pengaruh } \\
\text { Langsung }\end{array}$ & $\begin{array}{c}\text { Tidak } \\
\text { Langsung }\end{array}$ & $\begin{array}{c}\text { Pengaruh } \\
\text { Total }\end{array}$ \\
\hline Variabel laten $\eta_{1}$ terkait dengan BU (bobot umbi) & 0,903 & $-0,780$ & 0,123 \\
\hline Variabel laten $\eta_{2}$ terkait dengan DU (diameter umbi) & $-1,603$ & $-0,958$ & $-2,561$ \\
\hline Variabel laten $\eta_{3}$ terkait dengan JU (jumlah umbi) & $-0,964$ & - & $-0,964$ \\
\hline Kovariat BU $\times$ masing-masing faktor lokasi & $-1,385$ & 0,642 & $-0,743$ \\
\hline Kovariat DU $\times$ masing-masing faktor lokasi & 2,569 & $-1,309$ & 1,260 \\
\hline Kovariat JU $\times$ masing-masing faktor lokasi & 1,386 & $-0,944$ & 0,442
\end{tabular}

Hasil analisis SEM menunjukkan bahwa nyatanya pengaruh IGL hasil pada percobaan multilokasi dipengaruhi oleh IGL bobot umbi, diameter umbi dan jumlah umbi memberikan efek pengaruh langsung (Tabel 6) dengan standardized efek masing-masing adalah 0,903, -1,603, dan -0,964 seperti yang terlihat pada Gambar 3. IGL untuk komponen daya hasil bobot umbi memiliki efek langsung positif terhadap IGL hasil produksi. Hal tersebut mengartikan bahwa untuk bobot umbi bawang merah di atas rata-rata akan memberikan hasil produksi yang relatif lebih banyak. Namun, untuk IGL komponen daya hasil diameter dan jumlah umbi bawang merah memiliki efek langsung negatif terhadap IGL hasil produksi bawang merah. Hasil ini memberikan informasi bahwa jika diameter dan jumlah umbi bawang merah berada di atas rata-rata maka hasil produksi bawang merah relatif lebih sedikit. IGL bobot umbi memberikan efek tidak langsung melalui diameter dan jumlah umbi sebesar -0,78 dan IGL untuk diameter umbi memberikan efek tidak langsung melalui jumlah umbi sebesar -0,958. Total efek dari ketiga IGL untuk komponen daya hasil masingmasing diberikan sebesar 0,123 untuk IGL bobot umbi, -2,561 untuk IGL diameter umbi, dan -0,964 untuk IGL jumlah umbi, Dari diagram path SEM di atas, dapat diketahui pula keragaman dari IGL untuk masingmasing komponen daya hasil (Gambar 3), yaitu sebesar 0,976 untuk bobot umbi, 0,962 untuk diameter umbi dan 0,967 untuk jumlah umbi. Besarnya nilai tersebut menunjukkan bahwa model yang dianalisis dapat menjelaskan keterkaitan antara IGL komponen daya hasil dan pengaruh faktor-faktor genotip dan lokasi terhadap IGL komponen daya hasil.

Interaksi antara kovariat jumlah umbi $(\mathrm{JU}) \times$ kovariat masing-masing faktor lokasi memberikan pengaruh terhadap daya hasil produksi bawang merah sebesar 1,386 dan terhadap komponen daya hasil jumlah umbi sebesar 0,980. Tanda positif tersebut menunjukkan bahwa genotip dengan jumlah umbi di atas rata-rata dan ditanam pada lokasi relatif rendah, $\mathrm{pH}$ tanah di atas 6 serta kondisi tanah lempung berdebu akan memberikan hasil produksi bawang merah yang relatif tinggi dan jumlah umbi yang relatif banyak, Interaksi kovariat bobot umbi $(\mathrm{BU}) \times$ kovariat masing-masing faktor lokasi memberikan pengaruh terhadap komponen daya hasil bobot umbi bawang merah sebesar 0,988 . Hasil tersebut menunjukkan bahwa genotip yang ditanam pada lokasi relatif rendah, $\mathrm{pH}$ tanah di atas 6 serta kondisi tanah lempung berdebu akan memberikan hasil bobot umbi yang relatif berat. Interaksi kovariat diameter umbi (DU) $\times$ kovariat masing-masing faktor lokasi memberikan pengaruh terhadap komponen daya hasil diameter umbi bawang merah sebesar 0,814. Hal tersebut menunjukkan bahwa genotip yang ditanam pada lokasi relatif rendah, $\mathrm{pH}$ tanah di atas 6 serta kondisi tanah lempung berdebu akan memberikan hasil diameter umbi yang relatif besar.

\section{KESIMPULAN}

Berdasarkan hasil dan pembahasan yang telah diuraikan di atas, maka kesimpulan yang dapat diambil adalah hasil uji multilokasi tanaman bawang merah dengan 6 genotip yang ditanam pada 5 lokasi di Kabupaten Sigi menunjukan bahwa pengaruh utama genotip dan lingkungan serta interaksi antara genotip dan lingkungan memberikan pengaruh terhadap komponen daya hasil (bobot, diameter, dan jumlah umbi bawang merah) dan daya hasil produksi bawang merah yang ditunjukkan dengan nilai p-value lebih kecil dari $\alpha$. Dari hasil analisis SEM-AMMI didapatkan bahwa interaksi antara kovariat jumlah umbi dan masingmasing faktor lokasi memberikan pengaruh yang signifikan terhadap hasil produksi dan komponen daya hasil jumlah umbi. Begitupun interaksi antara kovariat bobot umbi dan kovariat masing-masing faktor lokasi memberikan pengaruh terhadap komponen daya hasil bobot umbi bawang merah serta interaksi antara kovariat diameter umbi dan kovariat masing-masing faktor lokasi memberikan pengaruh terhadap komponen 
daya hasil diameter umbi bawang merah. Hasil tersebut menunjukkan bahwa genotip yang ditanam pada lokasi relatif rendah, $\mathrm{pH}$ tanah di atas 6 serta kondisi tanah lempung berdebu akan memberikan hasil bawang merah yang relatif baik.

\section{DAFTAR PUSTAKA}

[1] D. Cahyanti, W. Ningsih, S. Kassa, and D. Howara, "Analisis Nilai Tambah Bawang Merah Lokal Palu Menjadi Bawang Goreng di Kota Palu,” Jurnal Agrotekbis, vol. 1, no. 4, pp. 353-360, October 2013.

[2] [PUSDATIN] Pusat Data dan Sistem Informasi Pertanian, Outlook Bawang Merah 2015. Jakarta : Pusat Data dan Sistem Informasi Pertanian Kementerian Pertanian, 2015.

[3] [BPS] Badan Pusat Statistik Provinsi Sulawesi Tengah, Provinsi Sulawesi Tengah Dalam Angka 2018. Sulawesi Tengah : Badan Pusat Statistik, 2018.

[4] E. Ambarwati and P. Yudono, "The performance of yield stability of shallot," Jurnal Ilmu Pertanian, vol. 10, no. 2, pp. 1$10,2012$.

[5] I. G. Nyoman et al., "Partial Least Square-Mixed Ammi dalam Analisis Interaksi Genotip x Lingkungan," in Seminar Nasional Sains dan Teknologi II, pp. 978-979, 17-18 November, 2008.

[6] P. Dhungana, K. M. Eskridge, P. S. Baenziger, B. T. Campbell, K. S. Gill, and I. Dweikat, "Analysis of Genotype-byEnvironment Interaction in Wheat Using a Structural Equation Model and Chromosome Substitution Lines," Jurnal Crop Science, vol. 484, pp. 477-484, April 2007.

[7] A. Nur, M. Isnaeni, B. Penelitian, T. Serealia, and S. Selatan, "Stabilitas Komponen Hasil sebagai Indikator Stabilitas Hasil Genotipe Jagung Hibrida,” Jurnal Penelitian Pertanian Tanaman Pangan, vol. 26, no. 2, pp. 106-113, 2007.

[8] Mattjik, A. A., and Sumertajaya, I. M., Perancangan Percobaan dengan Aplikasi SAS dan Minitab Jilid I. Bogor: IPB Press, 2006.

[9] Widiastuti, I., "Additive Main Effect and Multiplicative Interaction (AMMI) dan Aplikasinya," [Skripsi], Fakultas Matematika dan Ilmu Pengetahuan Alam, Universitas Negeri Yogyakarta,, Yogyakarta 2010.

[10] Johnson, R.A. and Wichern, D.W., Applied Multivariate Statistical Analysis, 3rd ed, New Jersey: Prentice-Hall, 1996.

[11] Jaya, I. M., "Analisis Interaksi Genotipe x Lingkungan Menggunakan Model Persamaan Struktural," M.S. thesis, Sekolah Pascasarjana. Institut Pertanian Bogor. Bogor. 2009.

[12] Noviyanti, E. "Analisis Biplot Untuk Pemetaan Provinsi Berdasarkan Prestasi Mahasiswa TPB IPB dan Nilai Ujian Nasional," [Skripsi] , Fakultas Matematika dan Ilmu Pengetahuan Alam Institut Pertanian Bogor, Bogor,2009.

[13] Pranoto, "Model Pengukuran Reflektif dan Formatif Dalam Structural Equation Modeling dengan Partial Least Square (SEM-PLS)," [Skripsi], Fakultas Matematika dan Ilmu Pengetahuan Alam, Universitas Lampung, Bandar Lampung, 2019.

[14] Wijanto, S., Structural Equation Modeling dengan Lisrel 8.8, Yogyakarta: Graha Ilmu, 2008.

[15] Joreskog, K. G., and Sorbom, D., LISREL 7:User's reference guide, Mooresville: Scientific Software Inc, 1989. 
